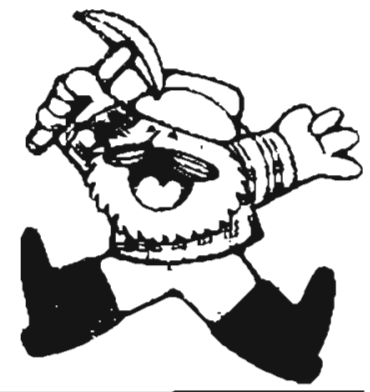

So.

P.O. Box 80007

vay S. Hammond-Governor
Published Quarterly

College, Alaska 99708

Robert E. LeReache - Commrenoner

Ross G. Schaff-State Geologist

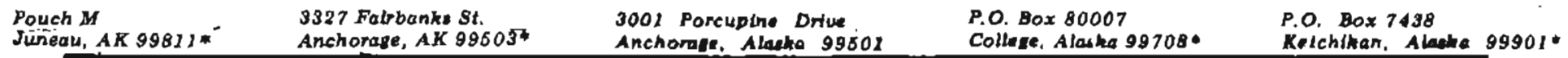

DGGS geologic hazards program gains momentum IN THIS ISSUE UA Museum publishes bibliography on Alaskan

Numerous natural resources bills in Legislature mining

Areas needing positive action by Legisiature in 1978

Mining claims continue to rise

DGGS issues call for 'Short Notes - 1978'

Federal attorney supports road okay

Role of the small miner

Barite prospect being developed near Haines

Two North Slope test wells successful

FEA compiles figures on private- vs gov't-owned oil companies

Date released on stratigraphic test well in lower Cook Inlet

MIRL relenges report on land withdrawals

Ecology and national security

Council hits Interior on d-2 mining data

Martin cautions d-2 resisters

Output of nonfuel minerals sets record in 1977

DGGS isales open-fille reports on Kodiak Island, new capital site

Comprehensive guide to 'tailings pond' design published by USBM

Birds of prey nest in Alaskan gold dredges
DGGS Assesses Alaska's 1977

Minerals Exploration and Production

by C.N. Conwell, DGGS mining engineer

Mineral exploration in Alaska jumped to an estimated $\$ 45$ million last year, according to DGGS estimates. Mineral production, on the other hand, dropped off considerably - to about $\$ 154$ million, down 35 percent trom the adjusted total for 1976. (These figures are exclusive of oil and gas.)

\section{MINERAL EXPLORATION}

Mineral exploration continued at an accelerated pace. A meaningful Indicator of the pace of exploration activity is the 17,378 new mining claims filed In 1977 , an increase of 31 percent over 1976 . There were 2,008 affidavits of labor filed on 44,146 active claims, which is 20 percent above the 1976 total. In addition, the total number of active mining clalms in the state in 1977 jumped to 61,524 , up 45 percent over the previous year. The amount expended on Alaska exploration for 1977 , once the final figures are known, will probably exceed $\$ 45$ million.

\section{Arctic Alaska}

of the estimated $\$ 15$ million spent in this area on mineral Investigations in 1977, one-third was invested exploration of the high-grade copper, lead, and zinc ore bodies north of the Kobuk River in the southwestern Brooks Range; these well-known stratabound volcanogenic massive sulfide deposits hold a proven reserve estimated at several blllion dollars. Several major companies conducted extensive explaration for uranium, particularly in the Selawik Hilis, the Ray Mountains, and Kokrines Hills. Substantial reserves of lead, zinc, and barite were explored near the Red Dog deposit, 50 miles east of Point Hope. Houston Oil and Minerals released preliminary drilling information on a similar deposit nearby.

\section{Western Alaska}

Expenditures in western Alaska are estimaled to have exceeded $\$ 7$ million. Cominco drilled on the Berg lead. zinc prospect and conducted geological studies th four areas. Placid Oil and Great Lands Exploration were busy in the Bendeleben and Candle quadrangles. Exxon, Cities Service, Wyoming Minerals, Union Carbide, and C.C. Hawley and Associates, who had a contract from Bendix, actively explored the uranium potential of the Seward Peninsula with emphasis on the Darby Mountains, Serpentlne Hot Springs, and areas that had indicated either anomalous radioactivity or radioactive minerals in placer deposits.

\section{Interior Alaska}

About $\$ 10$ million was expended on mineral exploration on the interior part of the state. A major uranium exploration program north of Healy was con. ducted by the German firm Urangeschellschaft, which drilled and conducted extensive ground and aerial reconnaissance; their expenditure alone is estimated at $\$ 2.5$ million. Insplration Consolidated Copper was again 
active in the Nabesna area (Orange Hill). Active exploraHon extended along the north flank of the Alaska Range trom Healy to Tok. Shortly after the field season, the U.S. Bureau of Mines announced the discovery of a radioactive anomaly near Mount Phindle, northwest of Fairbanks; a rush of claim staklng resulted. A limited amount of exploration continued in the Healy and Jarvis Creek coal fields.

\section{South-Central Alaska}

An estimated $\$ 5$ million was speat on metal- and energy-related resource investigations in this area. The greatest dollar expendlure was related to col exploration by Mobil Oil, AMAX, and AMEX in the northern part of the Beluga field and southern part of the Yentna coal field, with limited exploration occurring in the Susitna field. WGM, Inc. of Anchorage conducted an extensive evaluation program for uranium in the Cook Inlet area. Several companies explored the Wrangell Mountains for copper and related deposits.

\section{Southwestern Alaska}

Umited exploration continued on the base-metal veías in the Chignik Bay and Moller Bay areas. Bear Creek signed an exploration agreement with the Bristol Buy Native Corporation and searched for porphyry copper deposits on the Alaska Peninsula. The Department received several inquiries regarding the Chignik coal fjeld; bowever, no known exploration activity occurred.

\section{Southeastera Alaska}

Southeastern Alaska had a very heavy concentration of exploration, particularly for uranium on Prince of Wales Island (Standard Metals, Cotter, Exxon, and Amoco) and base metals on Admiralty Islarid. Pan Sound, a jolat venture that includes Noranda, Marietta Resources International, Mitsubishi, and Texas Gas Expioration, made substantial discovery of base and precious metals on Admiralty Isiand and released confidential Information on grade and tonnage for proposed federal reclassification of land in the Tongass National Forest. At least three companies were actively drilling near Bokan Mountain. Standard Metals reportedly discovered another ore body in the old Ross-Adams uranium mine at Bokan Mountaln. Inspiration Consolidated Copper continued drilling the copper-nickel deposits on Yakobi Island.

In November the U.S. Forest Service granted U.S. Barax a permit to construct a 13-mile road from the coast to their porphyry molybdenum deposit at Quartz Hill, 45 miles east of Ketchikan. Alyu Mining con-' tinued exploration on a barite and base-metal deposit nortbrest of Haines, near the Canadian border. The firm plans to mill 200 tons per day for a drilling-mud product and minor base metals. To develop this deposit, a permit was obtsined to construct a 7-mile road from the old town of Porcupine to Glacier Creek.

\section{MINERAL PRODUCTION}

The total mineral production, exclusive of ofl and gas, in 1977 is estimated at $\$ 154$ million, a decrease of 35 percent from the 1976 adjusted total of $\$ 237.7$ million. Accounting for this figure, in order of value, were sand and gravel ( $\$ 125$ million), bullding stone ( $\$ 10$ million), coal (\$8 million), and gold (\$7.8 million). Barite, thn, antimony, and gemstones contributed about $\$ 3.2$ million.

Gold production was estimated at 50,000 ounces from an estimated 200 small scale placer mines and the two dredges operated by Alaska Gold near Nome.

\section{DGGS Geologic Hazards Program Gains Momentum}

By R.D. Reger and J.R. Riehle, DGGS Geologists

The Big Picture

Because of its size, location, and complex geography, Alaska bas numerous geologlc hazards. In addition to processes that operate in other states (Dooding, shoreline erosion, snow avalanches, etc.), Alaska has bazardo related to permifrost, slushflow avalanches, and surging glaciers. Moreover, a zone of Intense seismic activity through southem Alaska exposes us to frequent earthquakes and their side effects (tsunamis, liquelaction, belching).

Alaska also contains the greatest concentration of active volcanoes in North America; in the past 277 years at least 41 different volcanoes have erupted and some, like Pavlov and Shishaldin, have erupted more than 20 times. Augustine Volcano, in lower Cook Inlet, poses a major threat because not only does it have a histary of frequent explosive volcanism, but if sea water enters the magma chamber (as happened at Krakatos in 1883), the resulting blast(s) could generate sea waves large enough to inundate parts of Alaska's most populous area.

Fortunately, Alaska's population is small and predominantly scattered, and losses of life and property to natural processes so far have been relatively minimal. Some 114 lives and $\$ 311$ million in property pere lost during the Good Friday earthquake of March 27, 1964. But only the timing of the event, which caught most people awry from normally congested areas, kept the losses this low.

Will we be this lucky again? Our population is not remaining small: It is growing, and most of the growth is cccuring in south-central Alaska, where great earthquakes are most likely to occur. Recent tigures (IIg. 1) indicate that Alaska's annual population growth has nearly doubled stnce 1970 (to about 18,520 person/yr), with most newcomers settling in the Anchorage area (11,360/yr). Thus, more people are being exposed each year to natural geologic processes, and they are forced to build on land that is only marginally suitable (subject to snow avalanching and periodic flooding or is under. ialn by ice-ricb permafrost). The terms of the next great earthquake might not be so 'cheap.'

Section 41.08 .020 of the Alaska Statutes charges DGQS with providting Inforration about geologic hazards to prevent unnecessary loss of life and expense. Legislative acts, such as the recently enacted Alaska 


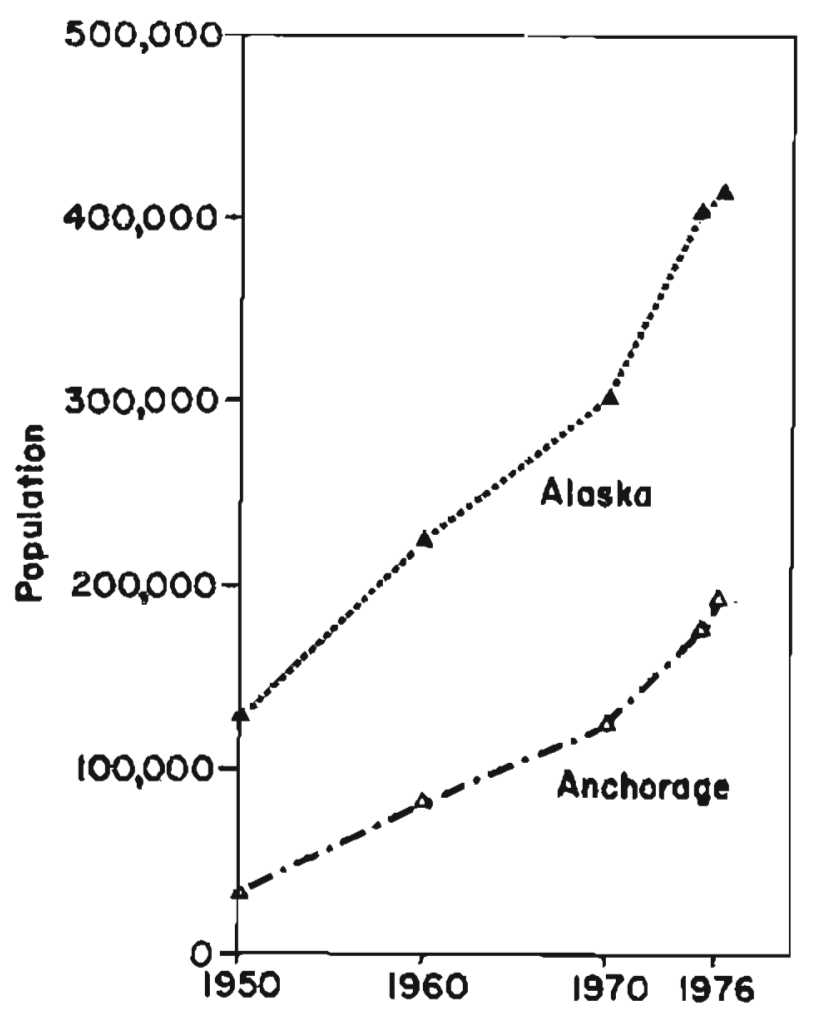

Figure 1. Population of Alaska and Anchorage, 1950-76. Data from Anchorage Chamber of Commerce (oral comm., Feb. 17, 1978).

Coastal Management Act, include requirements for assessing geologic hazards. State Geologist R.G. Schaff assigned primary responsibility for mapping surficial geology and evaluating geologic hazards to R.D. Reger (Fairbanks) and J.R. Riehle (Anchorage) with J.T. Kline and C.L. Carver (Fairbanks) and K.S. Emruel (Anchorage) assisting. Help in assessing geologic hazards has also been given by S.W. Hackett and D.L. McGee (Anchorage), and J.T. Dillon (Fairbanks).

Field Projects

Because of the dense population and accelerating expansion in the upper Cook Inlet basin, the initial DGGS geologic hazards program was focused there. Field work during 1976 was concentrated in the area between Talkeetna and Kashwitna east of the Susitna River. (1-5)* Last summer's field work in the PalmerWasilla area extended the Susitna segment of the Castle Mountain fault about $6 \mathrm{~km}$ eastward along the Little Susitna River to the vicinity of Houston. (6-7)

The DGGS Coastal Appraisal Program is in large measure concerned with geologlc hazards along Alaska's lengthy coastline. Although the objective of this program is a regional synthesis of published and original geologic duta, initial tasks were focused on specific sites of interest to other state agencies. ${ }^{(8-10)}$ Regional surveys of lower Cook Inlet began in 1976 and continued last

Numerals dosignate references. However, because of their excessive leneth. the references are not clted and may be obtained by contecting ether author. year with a program of mapping surficial deposits and evaluating hazards along the coast from English Bay to Kenai.(11-15) Reconnaissance mapping and data synthesis are completed for the coastal zone from Valdez Arm to Yakutat, (16-17) From published data, Dillon predicted the number, magnitude, and loci of earth. quakes in the western Gulf of Alaska for the dext 100 years. (18)

To augment our small staff, outside assistance has been enlisted through cooperative programs with other agencies. A joint fleld program with the USGS was initiated last April in the Yakutat-Icy Bay area (16) C.S. Benson and J. Kienle of the Geophystcal Jastitute received grants to evaluate the potentlal dangers due to the recent activity of ice-covered Mt. Wrangell(10) and to assess potential hazards of Augustine Volcano. (20) DGGS grants were awarded last year to R.L. Bruhn (University of Utah) for detalled stratigraphic studies of the active Castle Mountain fault to evaluate its earthquake potential, (21) to T.L. Pewe (Arizona State University) for a report on geologic bazands in the Fairbanks area, (22) and to R.G. Updike (University of Wisconsin - Oshkosh), for assessing hazards in the Prudh oe Bay oil field. (28)

\section{Future Activities}

Although considerable effort has been expended these past 2 years, the geologic hazards program has barely begun. Only about 7 percent of the surficial geology of Alaska has been reliably mapped at a scale of 1:63,360 or larger. High-priority future projects include continued studies in the Susitna and Matanuska valleys, in the southwestern Talkeetna Mounteins (Hatcher Pass area), and in Chugach State Park. A program of mapping surficial geology and assessing hazards along the west coast of lower Cook Inlet will begin thts summer. A detailed survey of snow and slushflow avalanches a) Alaska's highway system will also be started.

We expect to publish a survey of geologic hazards for the general public. This initial report will be followed by a series of more technical reports discussing specific hazards, e.g., snow avalanches, problems of frozen ground, and glacier hazards. Another series of hazards reports will emphasize communlty problems.

\section{DGGS Anchorage Office Assigned New Phone Number}

The Anchorage Porcuplne office has a new telephone number. Instead of the previous 274-8602 or 279-1433, which were being shared with the Division of $\mathrm{Oil}$ and $\mathrm{Grs}$ Conservation, all the Anchorage staff but one can be reached at the new number, which is $277-6615$. The exception is geophysicist Steve Hackett, who works in the $O$ il and Gas part of the building and shares their numbers. Mining-information specialtst Ona McBrlde, whose office is across town at 3327 Falrbanks St, can still be reached at 279-7691. 


\section{Numerous Bills Affecting Natural Resources Pending in Legislature}

Listed below are some of the bills introduced in the state House and Sente which, if passed, will have an effect on the natural-resource activities of the state. Because new legtslation is introduced daily, the list is not inclusive (HB . House Bill, SB - Senate Biil).

\begin{tabular}{l} 
Bill \\
\hline HB 73 \\
HB 82 \\
HB 159 \\
(SB 82) \\
HB 219 \\
HB 225 \\
HB 359 \\
HB 539 \\
HB 563 \\
HB 588 \\
HB 645 \\
HB 657 \\
HB 736
\end{tabular}

HB 750

SB 82

SB 107

SB 221

SB 250

SB 264

SB 277

SB 282

SB 350

SB 365

SB 374

SB 386

SB 431

SB 791

\begin{tabular}{l} 
Subject \\
\hline Keystone Canyon State Park \\
Sale of royalty oil \\
Department of Renewable \\
Resources \\
OCS shore faclity siting
\end{tabular}

Talkeetna Mts.

State Grazing Reserve

Homesteading

Renewable-resource

development incentives

Pipeline connections and

interchange

Kachemak lease repurchase

Supplemental appro. D-2, roy alty

Transferral of tide lands

Upper Susitna hydro study

Landsat quick-look system

Department of Renewsble

Resources

North Slope haul road

Confidential rpts. on oll \& gas wells

Production of natural gas

Disposal of royalty oil \&

gas

In-kind taking of royalty oil \&

gas

Geological, geophysical \&

engineering data

Department of Nonrenewable

Resources

Royalty oil \& gas transportation

Transferral of tide \& submerged

lands

Spec. appro., geothermal greenhouse,

Pilgrtm Hot Springs

Special appropriation, mineral-resource

dev. access road

Oil and gas production

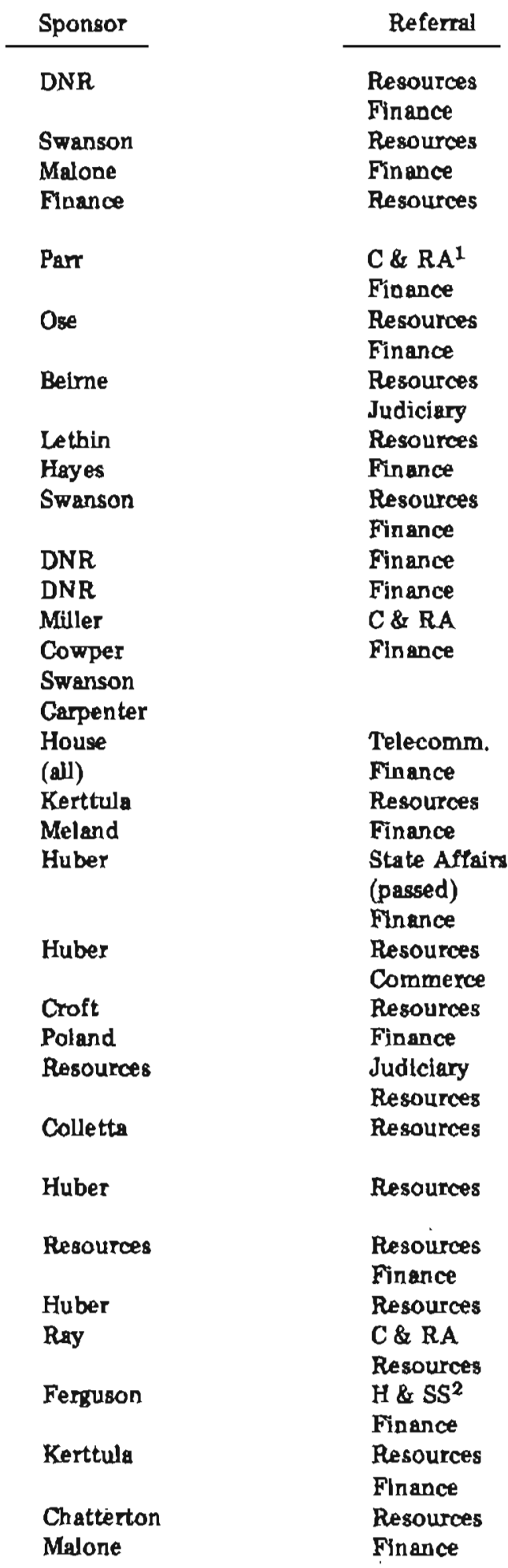

${ }_{2}^{1}$ Community and Regional Affalry.

${ }^{2}$ Health, Education and Social services. 


\section{Areas Needing Positive Action by the Alaska Legislature in 1978 \\ (from The Alaska Miner, Dec. 1977)}

WATER USE. Placer mining and hard rock mining are dependent on water. Two main areas of difficulty have emerged - water quality (administered malnly by DEC) and water as fish habitat (administered by DFC).

1. Water Quality. Alaskan logging, mining construction, and agriculture industries are baving trouble with water quality standards. Federal Water Pollution Control Act establishes an entirely new aim for water law - namely zero pollution. This objective has little or no basis in common law standards.

The Association is reviewing water standards affecting mining. It is not yet ready to recommend specific legislation. We point out, however, that the state's prime water quality standard - turbidity - is now technicaly recognized as non-measureable. Further, it is not being applied in a uniform manner.

New regulations should be based on measureable standards. There should be a recognition of type of use or type of stream involved.

2. Water as Fish Habitat. Department of Fish and Game now requires a permit be obtained by placer miners if the stream being mined has been specinied by the Commissioner as important for the spawning or migration of anadromous fish. Allegedly, the law has been used to stop mining for the sake of stopping mining.

As written. Title 16 does not differentiate between streams that are commercially important salmon streams, or those of minimal significance.

The Association agrees that oversight is necessary: however, a balance must he made between competing uses of streams with different values.

We recommend the legislature look at the approach taken in the Yukon Territory. There, a Water Control Board takes the position that use of water is the prime objective. It then attempts to adjudicate water use based on inputs from all potential users including the Fisheries.

GEOLOGIC AND MINING KNOWLEDGE. Alaska and its citizens have continual need for knowledge of its resource base. There is need for basic scientiflc information. There is need for technical assistance to Alaska citizens so they can compete with major corpoyations, and gradually build up an Alaskan-owned economy. We propose three specific areas where needs for knowledge should be addressed:

1. Geologic Mapping. At the present time, only about $7 \%$ of Alaska's land is geologically mapped in sufficient detail for intelligent land use decisions. Mineral assessment, water resource data, availability of bullding material, and identification of geologic hazards all follow from careful, detailed geologic mapping at a scale of at least 1 inch $=1$ mile. We ask that the Legislature mandate the appropriate State-funded institutions and agencies to systematically carry out this vital function.
Progress should be monitored by the Resources Committees on a yearly basis to ensure that the program is successful. The Alaska Legislature should request that appropriate federal agencies address the same objective.

2. Research into Mining Technology. Mining raethods are in a continuous state of development. The small Alaska miner does not have the capability to fund basic research. New methods of processing placer gravels with minimal water use are in current development. We ask that appropriate State-tunded institutions and agencies be mandated to evaluate and test such new methodology witb the objective of meeting Alaska's needs for mineral development and environmental safeguards.

3. Coal Research and Education. Public Law 95-87, "Surface Mining Control Act and Reclamation Act of 1977" became law on August 3, 1977, and allows matching Federal Funding to carry on the work of a competent and qualified mining and mineral resources research institute at one School of Mines of a public University. Title VIII allows not more than one coal laboratory to be located in single state and that at least one coal laboratory be established within each of the major coal provinces recognized by the Bureau of Mises, including Alaska. State legislation providing matching funds may be required to allow such programs to be activated in Alaska

DEVELOPMENT OF AN ALASKA-BASED IN. DUSTRY. The Association believes that the state can prudently use state monies, including the Permanent Fund, to gain long term income for the state by advancing or loaning funds for development purposes.

1. We propose legislation modeled after the federal DMEA-OME program to use Permanent Fund revenues to finance qualified small mining projects (small miners be defined a la Delcour). Loans would be subject to the same constraints as were federal loans, e.g. qualified personnel, a comprehensive plan showing how the monies would be spent, and executive monitored by qualified personnel from the Geological Survey. Loans would be paid back from the first ore sold from the developed mine. Such legislation would encourage the growth of a viable minerals industry throughoul the State and benefit the private citizens of Alaska.

Reactivating State Road Assistance Funds. The state has two unfunded road assistance programs on the books. Admitedly, road assistance programs have had varied success, however, the Association believes if the projects are monitored similar to a DMEA development process, the state can ultimately recover its seed money through an expanded private sector. We propose that this program be gradually reactivated.

In a general context, we propose this legislature aim at making Alaska self-sufficient in many areas. Alaskans themselves will benefit directly. We will quiet the violent economic swings caused by being too dependent of the Federal Government and outside capital.

We propose a planned state-wide transportation net would be as beneficial as anythiog Alaskans could do to 
advance the state. We belleve there is sufficient knowledge so that this net could be designed not to interdict major wildlife patterns. We believe such a net could be designed to protect village privacy, yet allow nearby access to goods and services.

Alaska Miners Association, Nov. 23, 1977

\section{Mining Claims Continue to Rise}

The number of clains flied during December, January, and February totaled-ready for this, five-card-stud tans?-6,666. Most were filed in December, 4,303. A tapering off occurred in January $(1,633)$ and in February, in which 730 new claims were fled with district recorders. The last 3-month period had 6,389 nev location ootices filed.

UnPortunately, a breakdown of claims by recording district was not available at Bulletin press time. We will try to print these figures in the next issue.

\section{DGGS Issues Call for 'Short Notes - 1978' Manuscripts}

DGGS is issuing its annual call for short manuscripts for Geologic Report 61, "Short Notes on Alaskan Geology - 1978." If you wish to have one of your brief scientific articles included in this annual series, the deadline is April 15.

No more than six double-spaced manuscript pages (1,800 words) Including references, figures, maps, and tables will be accepted for publication. Contrlbutors are generally limited to one authorship (or coauthorship) per report. All igures, maps, and tables must be black and white (and camera ready), and suitable for reduction to 8 meximum size of $8-1 / 2$ " $\times 11$ " (including margins) when submitted. Two copies of the manuscript, typed. double-spaced including references and figure captions, together with two clearty legible coples or prints of all illustrations, should be submitted to Editor, DGGS, College (p. 1). All material will be reviewed by the DGGS staff before being accepted for publication. Contributors should keep original copies of all material submitted, and while being reviewred it should not be submitted elsewhere for publication.

Copies of the 1977 issue of 'Short Notes' (Geologic Report 55) are still avallable. The 47-page book has 10 articles and costs $\$ 2.50$. (The inaugural issue, Geologic Report 51, which covered geologic innovations in 1976, is out of print.)

Most of the early gold prospectors in Alaska carried mercury to recover gold. They usually had rye whiskey, kerosene, and an elixir called Davis' Pain Killer In their caches, too.

To tell the temperature in winter, they'd put a quantity of each in a tin can and leave it outside overnight. Mercury troze at $-36^{\circ} \mathrm{F}$, the booze at $-55^{\circ} \mathrm{F}$, and the kerosene at $-63^{\circ} \mathrm{F}$. If the pain killer froze $\left(-70^{\circ} \mathrm{F}\right)$, they generally stayed indoors and drank it.
Federal Attorney Supports Road Okay

(from Ketchikan Daily News, Dec. 31, 1977)

A U.S. Department of Agriculture attorney has said that a Ketchikan district forest supervisor acted cor. rectly in allowing a permit for an access road from the Keta River to U.S. Borax's Quartz Hill mining site, 43 miles east of Ketchikan.

That permit has been questioned by the Council on Environmental Quallty and is being appealed by a coalition of conservation and fishermen's groups on several points.

In a letter to CBQ, Forest Service Ketchikan Supervisor Jim Watson responded to CEQ's arguments. CEQ has charged that the final envoronmental impact state. ment was inadequate, that a road would jeopardize land use decisions, that the Forest Service used improper interpretation of department authority and that U.S. Borax failed to tile an operating plan.

In response to the forest service's authority to issue a road permit, regional forest service attorney Amo Reifenberg said, "I belleve (Watson) attempted to follow the directive of the National Environmental Protection Act to use practicable means both to protect the environment and the economic requiroments of present and future generations of Americans.

"The forest service manual recogntzes that mining and wilderness are two mutually exclusive values, but Congress has provided for their coexistence. CEQ urges you to interpret the law and regulation so as to make it practically impossible to develop a mine. I believe that was not the intent of Congress in passing the Wildemess Act," he said.

Reifenberg argues that U.S. Boras would be wasting helicopter fuel, in the event that the mine later proved productive enough to warrant a road and a full-seale operation. This he sald was "contrayy to the President's emphasis on energy conservation."

"The department's authority relating to the subject of access to a valio mining claim inside a national forest is found in the Organic Act" and "provides that mineral lands in national forests continue to be subject to the mining laws."

A subsection directs the (forest service) chief to ugrant appropriate access across national forest and other lands. The directions to the Forest Service are to grant appropriate access."

In evaluating the raad permit, the Forest Service prepared an environmental statement.

CEQ argued that helicopter access would be cheaper than an access road and is feasible, Relfenberg sald.

"Even if the company does not plan to develop a mine, you find that the road will not cause unacceptable environmental impact and could be converted into an excellent trail," he sald.

He also pointed out a Forest Service directive which states that finally approved access method must have the "least impact on the wilderness resource while still reasonably serving the needs of the prospect." 


\section{The Role of the Small Miner \\ (By David W. Delcour, AMAX, Inc., Golden, CO)}

The role of the small miner in today's economy has become central to the debate over pending federal proposals to impose tighter control over access to minerals located on public lands. Critics of these. proposals have stated that they will force the small miner out of business. Supporters, on the other hand, deny that the small miner is any more than a memory of another era.

As we have followed the debate over the Federal Land Policy and Management Act of 1976, the recordation and surface management regulations promulgated or proposed thereunder, and legisiation to replace the location-patent system with a leasing system, we have understood both sldes to be aware of the problems which may be caused for the small miner. For that reason, we believe it is necessary to determine the precise role of the small miner in the United States in the last quarter of the twentieth century. Is he making the type of contribution which justifies concern for his well-being? Or, is he just an axacbronism whose memory stands in the way of modern public land management?

Who is the Small Miner?

Although the public record is replete with references to the small miner, we were extremely surprised to learn that no comprehensive definition of the term has been generally accepted. In talking to the numerous people initially contacted in connection with this study, we found knowledgeable persons perceiving the small miner as anything from the romanticized old prospector with pick and burro, to relatively substantial corporate ventures consummating millions of dollars of business every year. For purposes of this study, a small miner is an individual, partnership, or corporation which is not listed on a major stock exchange; or which has capitalization of less than $\$ 1,000,000$; or which employs fewer than 50 persons; or which produces less than 200,000 tons per annum of coal, industrial minerals, or sedimentary materials requiring further processing; or which mines or extracts less than 50,000 tons per annum of igneous or metamorphic rock requiring mineral beneficiation.

The defrnition is admittedly arbitrary, but it is one with which most people we surveyed feel they can agree. The various parts of the definition were provided. by many people: the "major stock exchange" ex.' ception and capitalization minimum were arrived at after talking to a number of mineral economists; the Mining Enforcement and Safety Administration (MESA) defines a mine with fewer than 50 employees as a small operation; the American Mining Congress and the National Coal Association provided the 200,000 tons per annum figure for coal; and a number of uranium producers and several of the responding companies suggested the 50,000-ton figure for extraction of igneous or metamorphic rock.
Having arrived at a generally acceptable definition of the small miner, we next sought to measure the small miners' Impact on domestic mineral production.

Most Mining Operations are Small

If one looks solely at the number of people employed by minlng operations, it quickly becomes clear that there are many more small mining operations than large ones. In 1976, the Bureau of the Census published a Census of Mineral Industries - 1972, which showed that 79\% of all mining operatjons in the United States 'employed fewer than 20 persons.

According to Congressman Jim Santina of Nevada, $64 \%$ of the nonfuel mining operations in this country today are conducted by nine or fewer men.

In Colorado, which keeps its own statistics on mineral production, $80 \%$ of the mining operations would fit into the small miner category on the defintion of employment alone.

MESA statistics for February 1977 showed that of 757 operators mining locatable minerals, 571 , or $75 \%$, fit into the small miner category of fewer than fifty persons employed.

While it is interesting to note the numerical dominance of the small miner, that fact alone is insufficient to demonstrate any significant contribution to the nation's mineral inventory.

\section{Barite Prospect Being Developed Near Haines \\ (from Aloska Business News Letler, Dec. 23, 1977)}

About the only bright spot on the horizon for the hard rock mining industry in the state this year is a barite deposit about 40 miles from Haines, near the Canadian border, which is expected to be in production after 1978. Phil Holdsworth, a former state commissioner of natural resources and curreotly a mining consultant, is a director of the Alyu Mining Corp. which owns the 3,000 acres of staked land located on federal acreage 7 miles off Mlle 37 on the Haines Cutoff. The prospect was discovered in 1968 by Merrill Palmer of Haines and is exposed intermittently along the surface over \& 2,000-foot area along a mountalnside. Holdsworth estimates the barite exposed on the surface is enough to supply the Alaska drilling lodustry for 20 years. Barite is used in oil-well drilling to make mud, which is used to lubricate the drill bit and float drill cuttings to the 'surface.

Principals In Alyu (for Alaska-Yukon) include Palmer, Lutok Stevedoring and Construction $\mathrm{Co}$. of Haines, two other Haines men and an Whitehorse resident. The company recelved a letter of entry from the state September 7 to bulla a 7 -imile road to the prospect. In about 3 weeks, construction crews pushed 3 miles of road in to the site across state lands in an area that is slated for logging in the near future. The final 4 miles are to be pushed through in the spring to reach the prospect, which will be drlled out to determine the size of the entire deposit.

About $\$ 150,000$ has been spent so far, primarily on 
staking and helicopter support. The project is estimated to require a tatal capital investment of about $\$ 3$ million. After the drilling program is corapleted and assuming a decision to go abead with the project is made, a mill that will crush and grind 200 tons of ore a day will be bullt The mill is expected to produce about 170 tons of barite a day through flotation, as well as 25 tons a day of tailings and 5 tons of zinc and silver sulfite concentrates from the Upper Glacier Creek site.

About a half dozen mud companles have historically controlled the market for barite because they offer the technical services the oil companies demand when drilling. Four of the companies beve reportedly expressed an interest in production from the mine. Production from the mill could be marketed in two ways, Holdsworth says. For the Kenai and Anchorage markets it can be moved in bulk pneumatically-it can be blown as a powder the consistency of flour onto trucks, taken to Haines and blown aboard barges or landing craft for the joumey to south-eentral Alaska. For the North Slope market the barite will have to be packaged in sacks so it can be flown or trucked to the wells there.

\section{Two North Slope Test Wells Successful (from Alaska Industry, Dec. 1977)}

The results of two successful North Slope test wells have been announced by Exxon Corp., U.S.A. The wells are located some $\mathbf{5 0}$ miles east of the Prudhoe Bay field and encountered an oil formation unrelated to Prudhoe Bay's formations.

Exxon reported that a test of its new Polnt Thomson well located on the Beaufort Sea coast showed an oil flow of 2,300 barrels a day and a gas-oil ratio of 5,800 cubic feet of gas per barrel of oil. The oil was 18.5 degrees gravity "pipeline quality" crude.

The announcement came following release of information on Exxon's Flaxman Island well, seven miles to the east. Exxon drilled the Flaxman Lsiand well two years ago. Results of that well indlcate an oll flow of 2,500 barrels a day and a ratio of 985 cubic leet of gas.

Exxon said it is encouraged by the results of the Point Thomson and Flaxman Island wells but that additional drilling is needed to determine if the two finds are part of the same field. Exxon has applied for a slate drilling permit for another well at a site four miles east of the Polnt Thomson well. That well was drilled on a 40,768-acre unit containing leases sold in the state's 1969 Pnidhoe Bay lease sale and operated by Exxon.

The new discovery is expected to heighten interest in a proposed lease sale of state acreage covering the three-mile zone in the Beaufort Sea.

Call of the Wild......Bradford Angier, author of Living off the Country, Survival with Style, Bobcats Before Breakfost, We Like It Wild, Edible Wild Plants, and The Master Backwoodsman, lives in a condominium. Sports Ilustrated.

\section{FEA Compiles Figures on Private- vs. Government-Owned Oil Companies}

The following table, a excerpt from An Evaluation of a Federal Oil and Gas Corporation, prepared by the Federal Energy Administration Office of Oll and Gas, denotes the relative performances of six private oil companies versus six foreign govemment-owned oil companies.

Average of six Average of six

Performance private company government compaoy values values

Net income as

a percent of

gross revenues

8.4

3.1

Net íncome as

a percent of

equity

Barrels per day

of production

per employee

Barrels per day

of refinlng per

employee

36.4

Annual revenues per employee $(\$ 000)$

Asset value

per employee 168 73

\section{Data Released on the Stratigraphic Test Well in Lower Cook Inlet}

The U.S. Geological Survey released open-file report 78-145 on an offshore stratigraphic test well drilled in lower Cook Inlet during 1977. The 48-page report contains a correlation section and a reduced geophysical log with litbological descriptions.

The purpose of the well, which was drilled in 216 feet of water and bottomed at a depth of 12,387 feet, was to acquire geologic, geophysical, and geochemleal data about the hydrocarbon potential of the rocks from the continental margin in lower Cook Inlet. This tnforma. tion was used in the evaluation of the tracts offered in the Outer Continental Shelf (OCS) Lease Sale No. CI on October 27, 1977. The report, "Geological and Operational Summary, Atlantic Richfield Company Lower Cook Inlet, Alaska, COST Well No. 1," by John C. Wills and others, may be inspected at the Conservation Division, 800 "A". Street, Ancharage.

Bumper sticker seen in UA Geophysical Institute parking lot: STOP CONTINENTAL DRIFT'. 


\section{UA Museum Publishes Bibliography on Alaskan Mining}

The University of Alaska Museum has released an exhaustive source document entilled "Alaska Mining History," by Virginia Doyle Heiner. Primarily an Alaskan mining bibliography, the 463-page tome also contains an index of mining community names and their variations and a biblingraphy according to mining areas of the state. A brief section at the end lists other sources of information (by author and year) on such subjects as mining law, mineral resources, railroads, tent cities of old. and even E.T. "Cap" Barnette and the hoary Washington-Alaska Bank of Fairbanks.

The bonk costs $\$ 6.50$ over the counter. For mail orders, add 75 cants for postage and handling. The book, History and Archaelology Serjes 17. may be obtained only from the Lniversity nf Alaska Museum. Fairbanks. AK 99701.

\section{MIRL Releases Report on Land Withdrawals}

The UA Mineral Industries Research Laboratory has issued MLRL report 40. "Compilation of the Data on the Land Withdrawals in Alaska." The document was published under a grant with the U.S. Bureau of Mines "to determine the amount of land open to mineral entry and location in Alaska under the federal mining laws and the state mining and mineral leasing laws."

There are about 2,600 land orders and acts classifying land in the state that restrict the use of our mineral resources, according to the report, and that about " 26 percent of Alaska. of $100.875,391$ acres, was open to mineral entry and location." Written by P.A. Metz and others, the 17-page publication contains two plates. It costs $\$ 2$ and is available only from MIRL. University of Alaska, Faírbanks 99701.

\section{Ecology and National Security (from Science, v. 198, p. 712)}

The traditional equation of national security with military might is becoming increasingly incongruous as resource scarcities. overpopulation, and the ravage of ecosystems are becoming ever more disruptive of economies and social structures around the world.

That is the messaze of the latest report from Worldwatch Institute, headed by Lester Brown. In the report, entitled "Redefining national security," Brown goes through the usual grim cataloging of disastrous global develnpments: the imminent end of the petroleum era (world oil production is expected to slide starting in the early 1990's), the spread of deserts. deforestation, soil erosion, overgrazing, and overfishing.

These developments lead in turn to increased poverty, rising food prices, rising unemployment. and resultant social and economic upheavals. There are already plenty of examples of such disruptions, Brown says. In Ethiopia the termination of Haile Selassie's rule was precipitated by a food crisis that resulted from ecological deterioration. The Egyptian government was nearly toppled by riots over climbing food prices. The catastrophic flood in Bangladesh was in large part due to deforestation of watersheds. And "for some countries." writes Brown, "encraaching deserts pose a far greater threat than invading armies."

It is not only in marginal economies that such stresses threaten national stability. At a press conference held to discuss his report, Brown referred to a speech the day before by Defense Secretary Harold Brown, who said that future fuel shortages posed the single greatest threat to national security. Without assured oil supplies, observed the secretary, we will find ourselves with "A useless, encrusted modern-day Maginot Line." Lester Brown also quoted Isaac Asimov to the effect that "even a non-nuclear war cannot be fought because it is too enerfy-rich a phenomenon."

"The purpose of national security deliberations should not be maximize military strength but to maximize national security," writes Brown-"the threats to security may now arise less from the relationship of nation to nation and more from the relationship of man to nature."

Despite abundant evidence for this assertion, nations continue to spend more on military defense than on health or education or development of new energy sources. Indeed, "the development of new, "more effec. tive" weapons systems now engages fully a quarter of the world's scientific talent."

Brown says no way has been found to evaluate military and environmental threats and "translate them into an allocation of public resources that provides the greatest national security." The military has its early warning system and economists have thelr forecasts, but no early warning systems exist to forestall the collapse of eatire biological systems. Hence the surprising disappearance of the anchovy crop a few years ago, and the Sahelian famine, which was brought on by overgrazing and resultant desertification.

According to Brown's thesis. the redefinition of

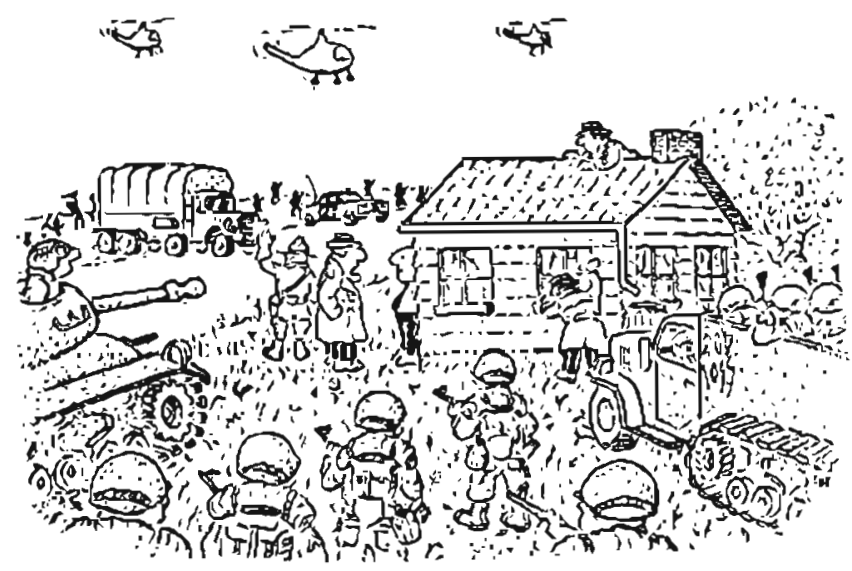

"We understand you tore the little tag off your mattress." 
national security will require a broad and entirely new interdesciplinary approach to the matter. But it may take a lot more disaster to forge such an approach. Brown said that at a recent college symposium he tried to get ecologists and economists to commu. nicate with each other, but they mixed like "oil and water."

Ziony Named Western Regional Geologist (excerpt from Interior Dept. news letter, Jan. 19, 1978)

Dr. Joesph I. Ziony has been appointed Westem Regional Geologist for the U.S. Geological Survey, Department of Interior, headquartered in Menlo Park, California. He succeeds George Gryc, who has taken an assignment in Alaska.

The Regional Geologist is in charge of research done by USCS's Geologic Division in the Western Region. The region includes Alaska, Arizona, Callfornia, Hawaii, Idaho, Nevada, Oregon, Washington, and the Pacific Trust Territories. Ziony, a specialist in earthquake hazards assessment, has served 16 years with the U.S. Geological Survey.

Council Hits Interior on d-2 Mining Data

(from Fairbanks Daily News-Miner, Jan. 10, 1978)

The Interior Department apparently did not use U.S. Bureau of Mines information on the mineral potential of some proposed d-2 lands when the Carter administration prepared its $d-2$ position last fall, representatives of Steering Council for Alaska Lands say.

According to research done by attomeys for the council, which was created last year to represent the state's position on the d-2 lands issue, the Bureau of Mines reports that were not used by Interior contain consistently higher estimates of mineral potential for some proposed $\mathrm{d}-2$ lands that the ones that were used.

The council filed a freedom of information petition in November to determine if the Interior Department suppresses or did not use pertinent Bureas of Mines information when the administration prepared its stance on the national interest lands.

The council staff said the Interior Department prepared a " $d-2$ briefing book" that was distributed to other federal agencies last summer for comment and suggestions on what the administration's d-2 position should be.

Attorneys for the council, who bave now examined the documents obtained under the freedom of information request, have told the council that the briefing book did not contain the Bureau of Mines mineral data.

Fairbanks Rep. Steve Cowper, chairman of the council and an unofficial candidate for Congress, sald, "Regardiess of the sequence of events preceding the issuance of the $\$ .2$ briefing book to federal agencies, it looks like the Bureau of Mines submitted data to the Department of Interlor which wasn't used when Interior made its position known to the other agencies."
He added, "Since the Bureau of Mines is part of the Department of the Interior, there was no way agencies like the Department of Energy could know that Interior had reports that showed a much higher mineral potential on Alaska lands. So you'd have to say that the administration's presentation was based on bad information."

People are very quick to assign "evll motives" In situations of this sort, Cowper said. But foul-ups do happen, he sald. "I'm not in any position to make moral judgements."

A memo to Cynthia Wilson, special assistant to the secretary, from Charles Eddy, acting assistant secretary for energy and minerals, says, "The briefing book needs substantial correction to accurately reflect the mineral values of the proposed areas...In particular, referring primarily to existing claims and their appraised values is not necessarily a realistic indication of mineral potential."

Cowper said that if the Bureau of Mines information had been provided, it might not have cbanged the administration's d-2 recommendations, but added, "We"l never know." He said the administration had detailed mineral maps from the state, but there's the question of whether those would be treated with the same weight as other information because the state is an interested party in the matter.

Attached to the memo, according to materials prepared by the council staff, are specific areas in which the energy and minerals assistant secretary said the briefing book did not correctly present the mineral potential of proposed d-2 lands.

Concerning the Gates of the Arctic, an area described as having one of the highest potentials for hard rock minerals in Alaska, the memo sald, "Contrary to the statement in the brlefing book, the southem one-third of the propased areas has a high mineral potential."

Another one of the 20 or so areas listed where Eddy's memo says the briefing book is incorrect is the Arctic National Wildlife Refuge.

"There are other areas whth potential for the occur. rence of copper, lead and zinc deposits other than the Chandalar district described in the briefing book," it says of the refuge.

The memo by Eddy is dated Sept. 12, three days before Interior Secretary Cecll Andrus delivered the Carter administration's d-2 proposal to Congress.

The administration proposed that more than 90 miltion acres of Alaskan land be placed in national parks, whllife refuges, wild and scenic rivers and national forests.

In late December, Wilson sald accusations that it suppressed Information vital to the d-2 issue were talse. He said Cowper later responded by saying that the councll wasn't trying to distort the truth about the administration's $d-2$ position, but merely checking out a report that information on the state's mineral potential hasn't reached the people who made the final decision on the administration's d-2 position. 


\section{Martin Cautions d-2 Resisters \\ (from Fairbanks Daily News-Miner, Feb. 13, 1978)}

Those who choose to resist instead of negotiate in setting the size of Alaska's d-2 package will lose out In the end, says Assistant Interlor Secretary Guy Martin.

Martin, at a news conference today prior to a speech before the Seattle Cbamber of Commerce, said setting aside a massive block of Alaska land for parks and wildilfe refuge already has been decided.

Resource development, he said, still is negotiable and the "fonal pattern will not be one that will be ob-" structive of resource development."

"There is real acceptance in the idea of natural interest lands being set aside in Alaska," Martin sald of the Carter Administration. At this point, he said, "what we are talking about now is what sort of tradeoffs should be made."

He said, "Those who choose controversy will reap what they sow." Martin, Alaska's former commissioner of natural resources, said the Carter Administration's proposal to protect 92 million acres of Alaska land is an effective compromise between environmentsl and economic interests. But he said even portions of the admintstration's plan are subject to further negotiations.

Three major areas of negotlation, he said, would be: access for transportation rights of way, entry for miaeral exploration and development and subsistence.

Martin said he chose the Chamber of Commerce forum because it involved people who were concerned about the economic future of Alaska resources.

He sald he expects the $d-2$ issue to be settled by Congress this year and that the administration's plan will not Impede Alaska's economic future.

Martin sald Interior Secretary Cecil D. Andrus, in setting up the boundarles for the Administration proposal, "largely avoided the areas of significant resource potential."

\section{Miners Association Holds Raffle to Buy Mine for Research, Education}

The Fairbanks chapter of the Alaska Miners Association is raffing off a 1.6-oz. gold nugget to help the University of Alaska purchase the Silver Fox Mine, located aear the Fairbanks campus. The mine, which has several drifts extending from the main 375-foot-iong adit, produced significant amounts of silver-lead ore a decade ago. Recent studies have revealed quantities of disseminated molybdenum in the associated country rock.

Seven other prizes Inlaid with placer gold, including lockets, earrings, pendants, and desk sets, will be given away at the Aprll 15 drawing, according to Emle Wolfs, branch president. Donations are $\$ 2.50$.

Alaska is the only state that has a flosting gold dredge still in operation.

\section{Output of Nonfuel Minerals Sets Record in 1977 \\ (Excerpted from Dept. of Interior news release Jan. 23, 1978)}

For the stxth year in a row, the value of nonfuel mineral raw materials produced in the United States set a new record, reaching $\$ 17$ blllion in 1977, Secretary of the Interlor Cecil D. Andrus said today.

Data provided by the Department's Bureau of Mines showed that the 1977 value of domestic nonfuel mineral production exceeded the 1976 value, $\$ 16.7$ billion, by 2 percent, Secretary Andrus said. Andrus noted that the $\$ 17$ billion worth of minerals was the basis for approximately $\$ 170$ billion worth of processed materlals of mineral origin.

Output of metals decreased $\$ 360$ million in 1977 , while that of nonmetals increased $\$ 670$ million. Of the 22 metals produced, output of 12 tncreased and the value of 13 increased. Among the 46 nonmetallic minerals produced, the quantity of 27 Increased and the value of 34 increased.

Mine production of gold declined 2 percent in 1977 to 1.02 million ounces, but value increased 16 percent to $\$ 152$ million. The decline was attributed to the copper strike at midyear, which reduced byproduct gold production. At the same time, significant new production entered the market as several new gold mines opened in the Western states. The price of gold ranged from a low of $\$ 130.25$ per troy ounce on January 11 to a high of $\$ 168.45$ on November 11. Consumption of gold remained essentially unchanged from the 1976 level at about 4.6 million ounces.

U.S. production of primary mercury increased 38 percent to 32,000 flasks, while the value of the product rose 65 percent to $\$ 4.6$ million as the average annual price climbed to $\$ 145$ per Iask, $\$ 10$ higher than last year. Consumptlon declined by about one percent to 64,220 flasks in 1977. U.S. dependence on forelgn mercury continued to decline, reaching about 46 percent in 1977.

Molybdenum shlpments rose 7 percent in 1977 to about 123 million pounds, worth $\$ 452$ million, a value gain of 36 percent. Reported consumption of molybdenum In 1977 increased about 7 percent over that of 1976.

U.S. mine production of silver totaled 37 million ounces, valued at $\$ 172$ million, up 9 percent in quantity and 15 percent in value from 1976 levels. Industrial consumption decreased 3 percent. Imports rose 7 percent and exports 16 percent. The average annual price of silver, $\$ 4.60$ per troy ounce, was about 25 cents above that of 1976 .

Sand and gravel sold or used in 1977 was about 898 million short tons, worth about $\$ 1.9$ billion, increases of 1 percent in volume and 5 percent in value over 1976. Stone production of 916 million short tons was up 2 percent over 1976. Value of the year's stone 
output was $\$ 2.3$ blliton, a record high, although the quantity was 14 percent below the 1973 record of 1.1 billion tons. Barite production reached an all-time high of 1.55 million tons, valued at $\$ 36.2$ million, both figures representing increases of 26 percent over the prevlous year.

\section{DGGS Issues Open-File Reports on Kodiak Island Oil Prospects, New Capital Site Geology}

DGGS recently released an open-file report on the petroleum potential of the Kodiak Island area. The report, written by both the DGGS and the U.S. Geological Survey, is based on a 1977 jotnt field project. The oll and gas potential of the area, from the sboreline to the 3 -mile $1 / \mathrm{mit}$, is described as "poor to lair." The report (described below) includes studles on porasity and permeability, source-rock and stream-sediment testing, age determination, and paleontology and palynology.

-AOF-114, "Tertiary formations in the Kodiak Island area and petroleum reservoir and source-rock potential," by DGGS and USGS staffs (55 p., $10 \mathrm{pl}$.) $\$ 4$ over the counter, $\$ 6$ postpaid.

Two open-file reports on the new capital site area will be available next month. They are:

-AOF-113A, "Reconnaissance geology of the new capltal site and vicinity, Anchorage quadrangle, Alaska," by R.D. Reger ( 1 pl. - scale 1:63,360). \$1.50. (Note: this AOF was incorrectly identified as AOF-114 in the last Bulletin.)

-AOF-113B, "Reconnaissance geologic-materials map of the capital site and vicinity, Anchorage quadrangle, Alaska," by R.D. Roger and C.L. Carver (1 pl. - scale 1:63,360). \$1.50.

The Energy Resources map of Alasks, announced in the last Bulletin, has proved to be exceedingly popular. The attractive 4 - by 3-foot may shows the location of known sources of oll, gas, coal, uranium, and geothermal nreas in addition to existing man-made facilities such as the trans-Alaska pipeline, power-generating plants, and transmission lines. The six-color map costs $\$ 2.50$ and is available from any mining-information office. Mail orders should be sent to the College office (c/o Mona Rector).

In a related vein, DGGS atill has copies of the Satellite Photomap of Alaska avallable. The black-andwhite photo mosaic shows detailed topography of all of the 49th state except the Aleution Chain and St. Lawrence Island. The map consists of five sheets and costs $\$ 7$.

Also available is an updated Information Circular 21 , "DGGS Open-File Reports," which lists the status of all such reports issued since the inception of the series. The 11-page document is free.

According to The Northern Miner, there are 15 producing gold mines in Canada today. In 1940, there were 146.

\section{Comprehensive Guide to 'Tailings Pond' Design Published by USBM \\ (from Dept. Interior news release, Jan, 25, 1978)}

An engineering gulde to the design and maintenance of safe, environmentally sound impoundments for disposing of noncoal mineral processing wastes has just been issued by the Bureau of Mines. The reference is almed at minimizing the potential safety and environmental hazards posed by the use of 'tailings ponds' to store the watery wastes from mineral processing plants. Thounands of tons of such wastes are dumped dally behind erabankments that creat the huge, permanent retaining 'lakes.'

There, over time, the solids sottle out from the water, which can be drawn off and recycled for plant use or discharged into nearby rivers and streams. If irnproperly bullt or malntained, however, the embankments can deterionte or even collapse, endangering people and property in the area. They can also be a source of air pollution, and the water in the tailings ponds is sometimes a cause of rater pollution that threatens animal and plant habitats.

The 136-page report costs $\$ 3$ and can be purchased from the Superintendent of Documents, U.S. Government Printing Office, Washington, D.C. 20402 (GPO Stock 024-004-01915-8).

\section{They Said It.....}

- "Mining men with capital and prospectors who can bring a substantial stake and who can aid in the development of the country are about the only classes to whom the (labor) field is open, and to them Alaska offers splendid inducements." -Dept. of Labor Bulletin 16, May 1898.

- "At one time, we could take our problems to the Administration-to the Department of Interlor-but today we see this agency as the source of our prob. lems." -R.C. Babcock, President, Northwest Mining Association.

. "A preservationist approach (to the $D-2$ issue) might best serve even the economic interests, for the potential of Alaska as a place for controlled tourism and recreation could, in the long run, far exceed the value of its mineral wealth. Oil and copper are exhaustible, but natural beauty is a boon for generations to come." -Smithsopian magazine, December 1977.

- "You can get much farther with a kind word and a gun than you can with a kind word alone." --Al Capone.

\section{Birds of Prey Nest in Alaskan Gold Dredges}

Dredges, elevated slutce boxes, dragline booms, and other gold-mining equipment are well suited as nesting habltat for large birds, particulary in treeless tundra areas or poorly developed forests. Gyrfalcons, other raptors, and ravens have used such equipment in Alaska, according to an artlcle by C.M. White and D.G. Roseneau 
in the ornithological publication Condor. I

Gyrfalcons occupied a nest under the top gantry of the Tweet Brothers gold dredge on the central Seward Peninsula almost continuously from 1956-63. Young falcons were successfully fledged in the nest while the dredge was in operation. Other falcons used a nearby dredge and plledriver (both abandoned) as nesting sites during the same period.

White and Roseneau revisited the area in 1968-69; the nesting areas were still being used, but this time by ravens. However, a large elevated sluice box near the Tweet dredge had an active nest with two young Gyrfalcons in it. According to the authors (1970), "The construction features of the sluice box offer a match for any cliff on the Colville River" (another well. known Gryfalcon nesting area). White and Roseneau also indicated that Rough-Jegged Hawks and Golden Eagles also build nests on Seward Peninsula gold dredges, structures that are 'cliffs' in the ecological sense.

DGGS geologists noted possible bird-of-prey nesting sites on abandoned dredges and dragline booms in the Livengood and McKinley mining districts.

\footnotetext{
${ }^{1}$ White, C.M., and Rogenbeau. D.G., 1970, Observations on food, resting, and winter populations of large North Amerlcan falcons: Condor v, 72(1), p. 118-115.

Our Gangie.....

by Frank Larson, DGGS editor
}

A reader from Billings, Montana sent us a game that seems destined to supplant the traditional 'nooner' (that is, bridge, cribbage, mumblety-oosik, or what-have-you) in popularity. Folks there are into "Frustration," a tongue-in-cheek endeavor that is billed "The exciting game of trying to obtain federal permits to drill an exploratory well." Avallable from Hart Publications (Box 1917, Denver 80201) for half a buck, Frustration is similar to Monopoly, wherein players move through a serpentine maze of obstacles by rolling dice. The winner is the first one to successfully drill. Some of Frustration's more whimsical steps include Nos. "1) Pay $\$ 20,000$ for geologic report... 17a) Only access is across BLM roadless area. Go directly to court... 17c) Rancher demands $\$ 5 /$ rod for 5 -mile access road. Pay $\$ 8,250$ or go to court... 17f) Immigrant-wagon ruts intersect proposed access roadway. Build $\$ 10,000$ detour... 30d) Archaelogist finds Indian garbage heap. Lose one tum while he sifts it to find how old it is... 30f) Rotting sheep herder's wagon found on location, declared historical site. More drill site, lose one turn... 47) Sur. veyor failed to place orientation stake, BLM doesn't know which way is north. Get surveyor back out, lose one turn... 49) Horse dung found on lease, wild-horse migratory route suspected. Wild Horse Friends threaten suit. Move site... 51) Young BLM staffer disagrees with surface owner over restoration, rancher runs him off. Lose two turns while repairing relations... and 56) Lease runs out before you get permit. Return to START."..... Needless to say, Frustration is, for the prospector, more than just an educational toy; rather, it's a glimpse of the Orwellian minerals future. Because of this, the game's popularity will probably decline and the traditional nooner will return to its place at the forefront of American midday pastimes....General Crude Oil apparently made it through the Frustration gamut, since they intend to continue exploring their DeLong Mountains prospect this year. Previous drilling in one 54-foot section last year encountered up to $34 \%$ lead-zinc and a high silver content.... Amarex, an Oklahoma-based flrm, is expected to start drilling a wildest test well on the Kenai Peninsula on Moose Point. The site is 5 milles from the productive Swanson River field.... On the legislative front, BLM is expected to set further guidelines on use of the surface of the ground in the extraction of the minerals below. (These Frustrations are for the unpatented mining-claim owner.)....In Southeastern, the historic Alaska Juneau mine may go back into operation. The mine, which yielded more than $\$ 80$ million in gold before being closed to FDR's legislative order L-208 in 1942, would yield a different commodity this time, however. A local corporation, Alaska Hydro Gardens, has asked the city fathers for permission to bulld a hydroponic farm in a decaying tunnel of the old mine and use it to grow fresh vegetables....Talk about Frustration: How about the old-time miners who mucked all day and then found they had to drlnk Diet Sarsaparilla or whatever because the old Organic Act of the Digtrict of Alaska prohibited the import, manufacture, and sale of alcoholle liquors? Well, you'l be relieved to know that in 1897 in Sitka a clvic-minded soul obtained a permit for 2,000 gallons of whiskey for "medicinal, mechanical, and scientific purposes." His altruistic motive apparently served the young city well, however, because the 12-gallon per-capita supply warded off all plagues ......... Nearer home, a geologist friend snapped a picture of a sodden DGGS hand, Cleland Conwell, pulling a rater-filled canoe back to the friendly shores of the Chatanika Rlver last summer. When asked if he had swamped, the crusty mining engineer replied, "Hell no. I was trying a new fleld methodWholesale Stream-Sediment Sampling.".....Lastly, our congratulations to DGGS geologist Wyatt Gllbert who, after many years of Sisyphean effort, finally managed to bag his first moose-a nice young bull. The klll was marred by a few minor details, however: He killed it in February. He killed it within Fairbanks city limits. He killed it in front of the local Fish and Game building. And he used an illegal weapon (his semiautomatic, recoilless, 780-cal. pickup). Oh, one more item: The next day, after he had been treated at the emergency ward for a wrenched back (be scuttled along as though he were trying out for the role of Quasimodo in the remake of "The Hunchback of Notre Dame"-all he needed was a hood, a bell rope, and a little string of saliva), his mailman brought him some news - a notice that his auto insurance had expired.... One has to wonder who his patron saint is. Certainly not Diana, Goddess of the Hunt... Perhaps an Englishman (T.S., Eliot)..Cheers. 
Metals Market

Feb. 17, 1978

Three Months Ago

Year Ago

Antimony ore, stu equivalent

European ore

$\$ 16.20-18.20$

$\$ 16.2-18.2$

$\$ 23.50-25.00$

Bartte (drilling mud grade per ton)

$\$ 19-28$

$\$ 40-42$

$\$ \quad 19-28$

$\$ 40-42$

$\$ 54-58$

$\$ 0.62$

$\$ 178.86$

$\$ 0.33$

$\$ 169.00$

$\$ 4.01$

$\$ 2.06$

$\$ 232.60$

$\$ 5.00$

$\$ 5.88$

$\$ 55.00$

$\$ 56-61$

$\$ 0.60$

$\$ 159.30$

$\$ 0.32$

$\$ 130.00$

$\$ 4.10$

$\$ 2.13$

$\$ 166.00$

$\$ 4.70$

$\$ 6.20$

Tin per lb., MW composite

$\$ 130.00$

$\$ 55.00$

TYtanlum ore per ton (ilmenite)
Tungsten per unit (GSA domestic)

$\$ 148.00$

Uranium per lb., MW US

spot oxide

$\$ 4244$

Zinc per lb. (MW US PW)

$\$ 0.305$

$\$ 41.50-42.50$

$\$ 0.305$

$\$ 17-28$

$\$ 40-42$

$\$ 38-46$

$\$ 0.68$

$\$ 136.60$

$\$ 0.29$

$\$ 166-16.6$

$\$ 3.45$

$\$ 2.41$

$\$ 162.40$

$\$ 4.53$

$\$ 5.16$

$\$ 55.00$

$\$ 139.15$

$\$ 41.42$

$\$ 0.37$

-Reproduction by Pdntine \& Dupleatton Services, Dept. of Administration, Anchorage-

State of Alaska

Department of Natural Resources

Division of Geological \& Geophysical Surveys

P.O. Box 80007

College, Alaska 99708 